\title{
Multiproxy study of anthropogenic and climatic changes in the last two millennia from a small mire in central Poland
}

\author{
Mariusz Lamentowicz · Zofia Balwierz • Jacek Forysiak • \\ Mateusz Płóciennik · Piotr Kittel · Marek Kloss • \\ Juliusz Twardy $\cdot$ Sławomir Żurek $\cdot$ Jacek Pawlyta
}

Published online: 19 May 2009

(C) Springer Science+Business Media B.V. 2009

\begin{abstract}
The Żabieniec kettle hole is the first peatland in central Poland analyzed quantitatively with four biotic proxies (plant macrofossils, pollen, testate amoebae and chironomids) to reconstruct the past environmental change. Palaeoecological data were supported by historical and archaeological records. We focused on autogenic vegetation change and human impact in relation to climatic effects. The aims of our study were (a) to describe the
\end{abstract}

Guest editors: K. Buczkó, J. Korponai, J. Padisák

\& S. W. Starratt

Palaeolimnological Proxies as Tools of Environmental

Reconstruction in Fresh Water

M. Lamentowicz ( $\square)$

Department of Biogeography and Palaeoecology,

Faculty of Geosciences, Adam Mickiewicz University,

Dzięgielowa 27, 61-680 Poznan, Poland

e-mail: mariuszl@amu.edu.pl

\section{Lamentowicz}

Ecosystem Boundaries Research Unit, Wetlands Research Group Station 2, Swiss Federal Institute for Forest Snow and Landscape Research (WSL), 1015 Lausanne,

Switzerland

\section{Lamentowicz}

Laboratoire des Systèmes Ecologiques Station 2, Ecole Polytechnique Fédérale de Lausanne (EPFL), 1015

Lausanne, Switzerland

Z. Balwierz · J. Forysiak · P. Kittel · J. Twardy University of Łódź, Faculty of Geographical Sciences, Narutowicza 88, 90-139 Lodz, Poland development history of the mire during the last 2,000 years, (b) to date and reconstruct the anthropogenic land-use changes and (c) to discuss a possible climatic signal in the peat archive. The combination of proxies revealed dramatic shifts that took place in the peatland since the Roman Period. Żabieniec was a very wet telmatic habitat until ca. AD 600. Then, the water table declined, and the site transformed into a Sphagnum-dominated mire. This dry shift took place mainly during the Early Medieval Period. Human impact was gradually increasing, and it was particularly emphasized by deforestation since AD 1250 (beginning of the Late Medieval Period). Consequently, surface run-off and aeolian transport

M. Płóciennik

University of Łódź, Faculty of Biology and Environment

Protection, Banacha 12/16, 90-237 Lodz, Poland

M. Kloss

Centre for Ecological Research, Polish Academy of

Sciences, Dziekanów Leśny, 05-092 Łomianki, Poland

S. Żurek

Department of Quaternary Studies and Nature

Conservation, University of Humanistic and Nature

Science of Kielce, Institute of Geography, Świętokrzyska 15, 25-406 Kielce, Poland

J. Pawlyta

Department of Radioisotopes, Silesian University of Technology, Krzywoustego 2, 44-100 Gliwice, Poland 
from the exposed soils caused the eutrophication of the mire. Furthermore, chironomids and testate amoebae reveal the beginning of a wet shift ca. AD 1350. Openness considerably increased in the Late Medieval and the Modern Periods. The highest water table during the last 1,000 years was recorded between AD 1500 and 1800. This wet event is connected with deforestation, but it could be also associated with the Little Ice Age. Our study shows plant succession in the Żabieniec peatland, which can be explained with the recent landscape transformation. However, such changes are also possibly linked with the major climatic episodes during the last two millennia, such as the Medieval Warm Period and the Little Ice Age.

Keywords Central Poland - Kettle hole - Testate amoebae · Pollen · Macrofossils · Human impact . Climate · Environmental archaeology

\section{Introduction}

Peatlands are very sensitive to climate change and human impact (Blackford, 1993; Charman, 2002; Rydin \& Jeglum, 2006). They record the hydrological and trophic variations within the peatland ecosystem as well as changes in the catchment area (Bragg, 2002). Many records from peat archives have proven to be useful for reconstructing the climatic changes (Schoning et al., 2005; Booth et al., 2006; Oksanen \& Valiranta, 2006; Chambers et al., 2007; Charman \& Blundell, 2007). However, other studies have concentrated mainly on the signal of human impact (Warner et al., 1989; Chambers \& Charman, 2004; Lamentowicz et al., 2007; Amesbury et al., 2008).

Wetland ecosystems function under various kinds of anthropogenic stress. Their present state is a result of a long history of changes. Disturbance was gradually increasing along with economic development in central Poland during the last 2,000 years. This period was also very important because of the phases of considerable climatic changes such as the Medieval Warm Period and Little Ice Age. Recovery of a disturbed peatland ecosystem is often not possible after it has passed a critical threshold. Therefore, it is important to assess the present condition and naturalness of peatlands. Moreover, the importance of human influence and climate should be estimated to understand the state of a mire ecosystem and the methods available for active nature conservation (Willis et al., 2007).

One of the major aims of late Quaternary palaeoecology is to answer the question: what is the proportion of the climatic to anthropogenic signal revealed in proxies? Late Holocene deposits are particularly challenging for palaeoclimatic inferences (Yeloff et al., 2007; van der Linden et al., 2008). Human activity not only transformed the forest vegetation in many parts of the world but also triggered indirect physical and chemical changes in peatlands. Since the Early Medieval period, the vegetation of European forests was considerably transformed (Ralska-Jasiewiczowa \& Latałowa, 1996; Williams, 2000; Ralska-Jasiewiczowa et al., 2004). Deforestations that progressed since the Medieval Age caused increased run-off and abrupt hydrological fluctuations. Furthermore, most of the European peatlands were drained (Joosten \& Clarke, 2002), which disturbed or eliminated the climatic signal from the peat archive. Consequently, multidisciplinary studies made at many sites are necessary to reconstruct spatially past environmental changes.

Recently, most palaeoenvironmental peatland studies have focused on ombrotrophic mires (Yeloff \& Mauquoy, 2006; Hughes et al., 2007; Sillasoo et al., 2007; Blundell et al., 2008), and a minority has been carried out in fens and kettle-hole mires (Lagerback \& Robertsson, 1988; Warner, 1993; Yu, 2006; Lamentowicz et al., 2008b), which can also provide interesting palaeoenvironmental data.

A typical feature of a kettle-hole peatland is the presence of a telmatic fen-bog transition in the stratigraphic sequence. The autogenic terrestrialization makes the reconstruction of a palaeoclimatic signal very difficult, although it is not impossible to detect it in subsequent stages of growth. Żabieniec in Central Poland is an example of a peatland where Sphagnum appeared and dominated in the following successive hydroseral stages. This may result from a natural trajectory to acidification (Hughes \& Barber, 2004) or even land-use change in the surroundings (Lamentowicz et al., 2007). Multiproxy palaeoenvironmental studies from peatlands with relation to historical and archaeological sources are not common in this part of Europe. They are particularly rare in the central part of our country, located in periglacial 
conditions during the last Ice Age. This is because most wetlands are concentrated within the former range of the last Vistulian (=Weichselian) Glaciation in the northern half of Poland, where a majority of studies were carried out.

The Żabieniec kettle hole is the first peatland in Poland and this part of Europe analyzed with four biotic proxies (plant macrofossils, pollen, chironomids and testate amoebae), which we compare with archaeological records in this study. Results of Cladocera and analyses of diatoms are currently being prepared for future publication. We focused mainly on the period of the last 2,000 years to track the increasing human disturbance that should have been recorded in the peatland. It was assumed that the most important hydrological and trophic change in the studied mire was initiated along with the beginning of the deforestation in the mire catchment in the Medieval Period. For this reason, the aims of our study were (a) to describe the development history of the mire during the last 2,000 years, (b) to date and reconstruct the anthropogenic land-use change and (c) to discuss a possible climatic signal in the analyzed peat archive.

Study site

The Żabieniec mire is situated in Central Poland, $25 \mathrm{~km}$ east of Łódź, in an area of morainic upland (Fig. 1). The mire is located in a closed oval basin, which is $1.5-\mathrm{km}$ long, in a watershed between the rivers Mrożyca (to the west) and Mroga (to the east). This basin was formed during the ice melting of the Warta Glacier as a melt-out depression with a highly varied bottom configuration. Żabieniec is situated in the central part of this glacial depression. The mire area is ca. 2.5 ha. Peat and lake sediments were deposited within this depression probably from the end of the Warta (=Saalian) Glaciation until the upper Plenivistulian (=late Weichselian). Biogenic deposits of the Late Vistulian and Holocene were formed only in the deepest part of the depression, i.e. in the Żabieniec mire basin.

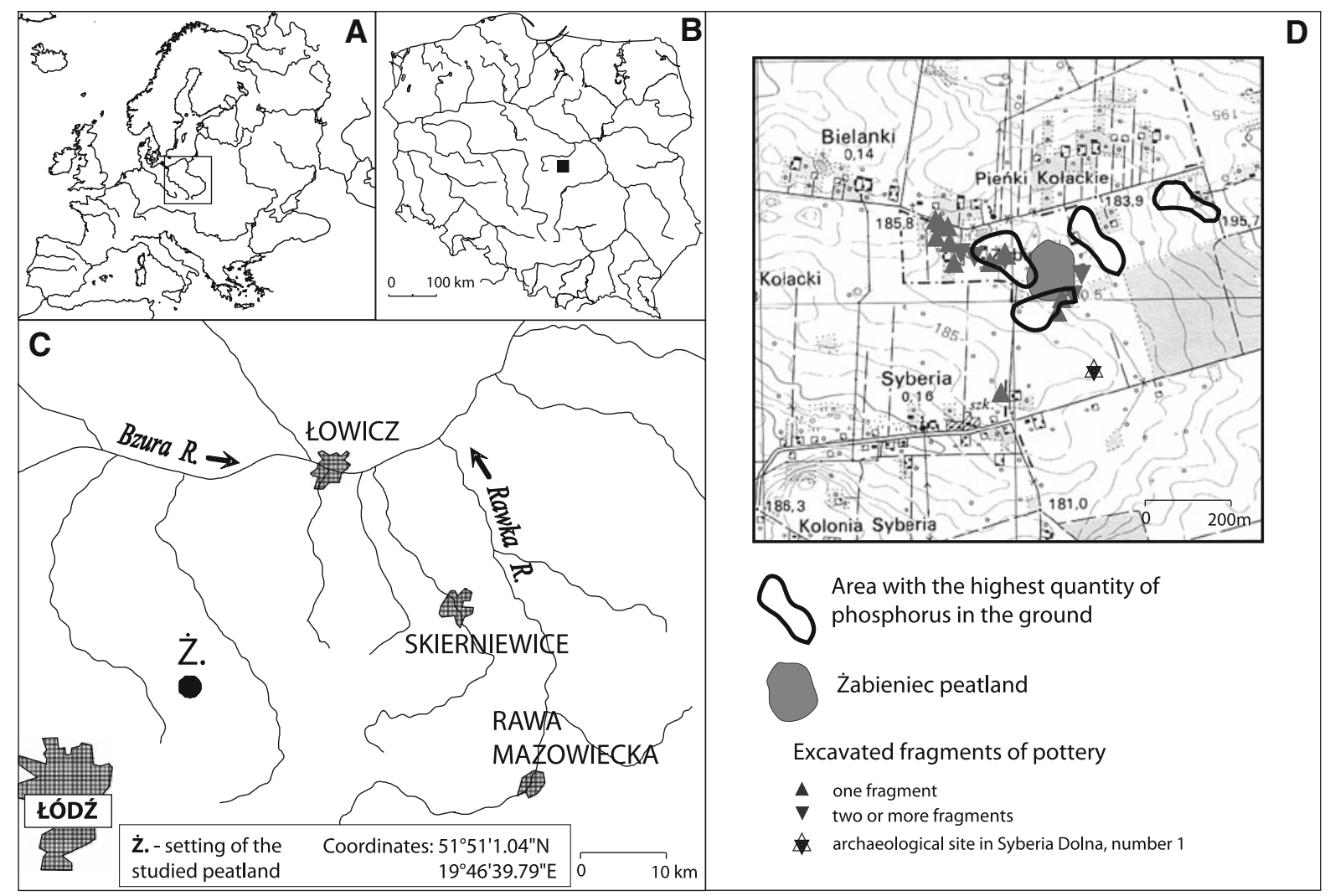

Fig. 1 Setting of the study site at the background of A Europe, B Poland, C central Poland and D map showing archaeological sites around the peatland 
Climate in this region of Poland is rather continental and drier than in the northern part of the country, which is more influenced by the wet air masses from the Baltic and northern Atlantic. According to the climatic typology of Poland, this area has a transitional climate (Woś, 1999).

The average annual temperature in 1931-1989 was $7.7^{\circ} \mathrm{C}$, while the mean of the warmest month (July) was $18^{\circ} \mathrm{C}$ and that of the coldest month (January) was $-3.3^{\circ} \mathrm{C}$. However, these annual and monthly temperatures are highly variable, which is probably caused by the influence of oceanic and continental climate. Average annual precipitation in 1951-1989 was $590 \mathrm{~mm}$, but in this case also, a high variability (ca. 30\%) was observed (Kłysik, 2001).

\section{Methods}

Fieldwork

One core (Z-2) was sampled from the central part of the mire (Fig. 2). In addition, a $60-\mathrm{cm}$ peat monolith was extracted for the study of the last millennium. The main core was taken with a piston corer. Furthermore, a geological survey of the mire was done with a Russian sampler (diameter-50 mm). Samples for phosphorus analyses were collected by geological drilling at depths of ca. 90-100 cm. Distance between drillings was 50-100 m. One hundred samples were collected for the analysis. Phosphorus analysis was realized according to the methodology described by Eidt (1973) and Arrhennius (1950).

\section{Laboratory}

An age-depth model for the peat profile was constructed by radiocarbon dating of the organic material (Table 1). Samples prefixed with 'Poz' in the laboratory code were dated with accelerator mass spectrometry (AMS), whereas all the other samples were dated with radiometric methods. All the AMS dates were obtained on the basis of several Sphagnum stems carefully selected for radiocarbon dating, avoiding any rootlets and other contamination (Table 1). All the other dates were obtained on the basis of bulk

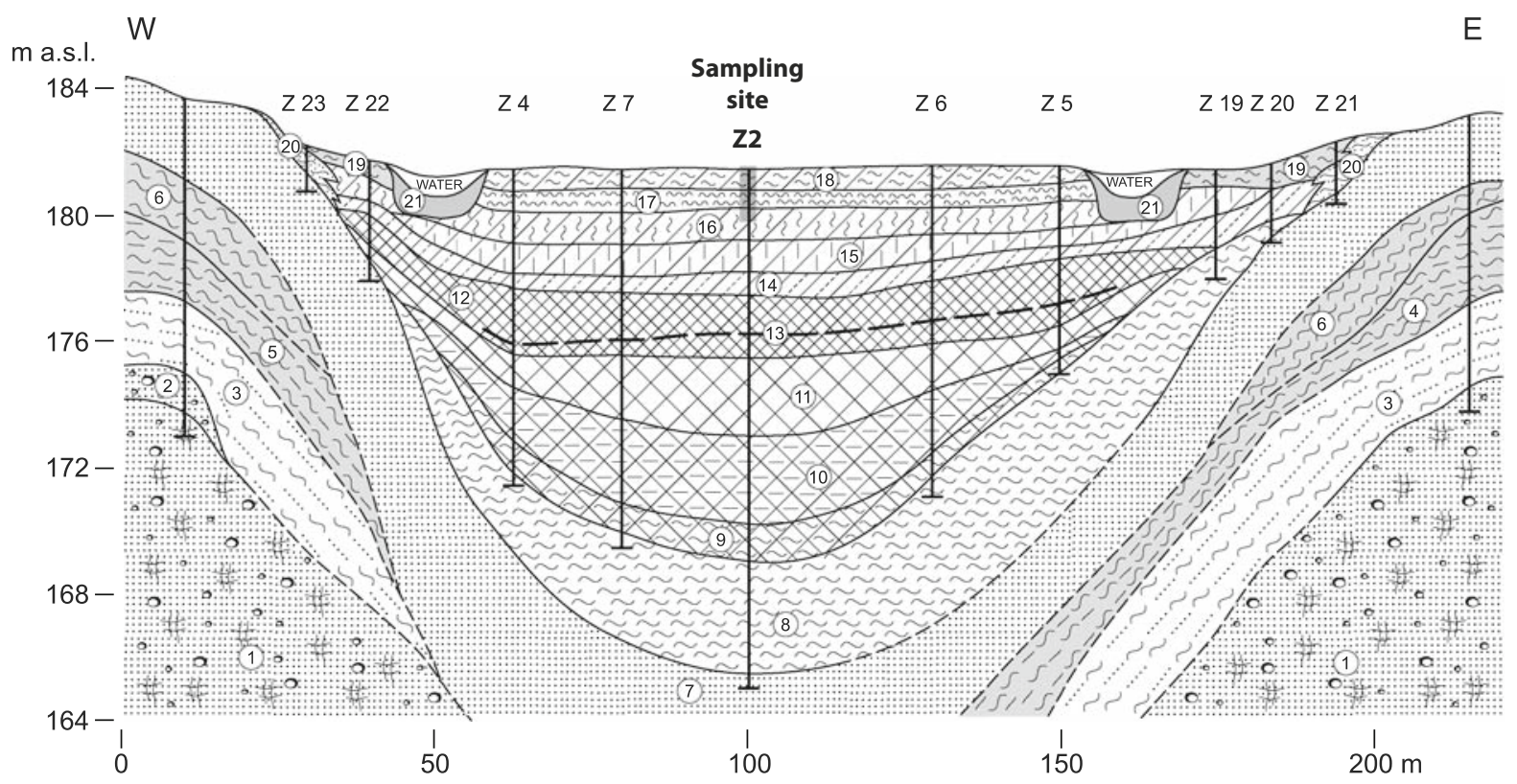

Fig. 2 Geological profile (WE) of the Żabieniec peatland. Warta Glaciation (=Saalian): 1—glacial till, 2-fluvioglacial sand and gravel, and 3-mineral silt; Eem Interglacial: 4organic silt; Vistulian (=Weichselian): 5-mineral-organic silt with fine sand, 6-organic-mineral silt, 7-sand, 8-mineral and organic silt, 9-gyttja with silt, 10-detritus-clay gyttja;
Holocene: 11-fine detritus gyttja, 12-coarse detritus gyttja, 13-brown-moss peat, 14-sedge-moss peat, 15-Sphagnum peat, 16-sedge-moss peat, 17-Sphagnum cuspidatum peat, 18-sedge-moss peat and brown moss peat, 19-organicmineral silt with detritus, 20-silt, 21-deposits disturbed by exploitation 
Table 1 Results of radiocarbon dating

\begin{tabular}{|c|c|c|c|}
\hline Sample name & Depth $(\mathrm{cm})$ & ${ }^{14} \mathrm{C}$ age $(\mathrm{BP})$ & Calibrated age ( $95.40 \%$ probability) \\
\hline Poz-19019 & 45 & $645 \pm 50$ & $1276 \mathrm{AD}(95.4 \%) 1405 \mathrm{AD}$ \\
\hline Poz-17117 & 60 & $1085 \pm 30$ & $894 \mathrm{AD}(95.4 \%) 1016 \mathrm{AD}$ \\
\hline Poz-17116 & 120 & $1475 \pm 35$ & $535 \mathrm{AD}(95.4 \%) 652 \mathrm{AD}$ \\
\hline Lod-1391 & 305 & $3010 \pm 50$ & $1410 \mathrm{BC}(95.4 \%) 1114 \mathrm{BC}$ \\
\hline Lod-1390 & 375 & $3690 \pm 50$ & $\begin{array}{l}2271 \mathrm{BC}(0.8 \%) 2259 \mathrm{BC} \\
2206 \mathrm{BC}(94.6 \%) 1937 \mathrm{BC}\end{array}$ \\
\hline Poz-23658 & 436 & $4580 \pm 35$ & $\begin{array}{l}3499 \mathrm{BC}(18.2 \%) 3436 \mathrm{BC} \\
3379 \mathrm{BC}(42.8 \%) 3318 \mathrm{BC} \\
3292 \mathrm{BC}(0.2 \%) 3290 \mathrm{BC} \\
3274 \mathrm{BC}(0.5 \%) 3268 \mathrm{BC} \\
3236 \mathrm{BC}(33.8 \%) 3108 \mathrm{BC}\end{array}$ \\
\hline Poz-23638 & 531 & $6270 \pm 40$ & $\begin{array}{l}5325 \mathrm{BC}(86.4 \%) 5204 \mathrm{BC} \\
5168 \mathrm{BC}(9.0 \%) 5076 \mathrm{BC}\end{array}$ \\
\hline Poz-23639 & 826 & $9130 \pm 50$ & $\begin{array}{l}8530 \text { BC }(1.2 \%) 8519 \text { BC } \\
8474 \text { BC }(94.2 \%) 8255 \text { BC }\end{array}$ \\
\hline Poz-23640 & 1,036 & $11,860 \pm 60$ & $11921 \mathrm{BC}(95.4 \%) 11609 \mathrm{BC}$ \\
\hline Poz-23659 & 1,290 & $14,120 \pm 70$ & $15286 \mathrm{BC}(95.4 \%) 14450 \mathrm{BC}$ \\
\hline
\end{tabular}

organic matter of peat. Both AMS and radiometric methods used the standard alkali-acid-alkali pretreatment procedure. Sample pre-treatment, graphite target preparation and ${ }^{14} \mathrm{C}$ concentration measurements for 'Poz' samples were done in the AMS facility of the Poznań Radiocarbon Laboratory. Radiometric dating for 'Lod' prefixed samples were done in the Łódź Radiocarbon Laboratory.

For the analysis of testate amoebae, $4-\mathrm{cm}^{3}$ samples were taken in $2.5-\mathrm{cm}$ intervals for the upper $60 \mathrm{~cm}$ and in 5-cm intervals for the section of $60-125 \mathrm{~cm}$. Samples were prepared according to the sieving and back-sieving procedure described by Hendon and Charman (1997). Testate amoebae were identified and counted to a total of 150 individuals per sample, at a magnification of $200-400 \times$. Their identification was based on the available literature (Grospietsch, 1958; Ogden \& Hedley, 1980; Charman et al., 2000; Clarke, 2003; Mitchell, 2003).

For pollen analysis, $2-\mathrm{cm}^{3}$ samples were taken in 5 -cm intervals and treated with $10 \% \mathrm{KOH}$ and then acetolyzed for 3 min (Berglund \& Ralska-Jasiewiczowa, 1986; Faegri \& Iversen, 1989). Minerogenic matter was removed with hydrofluoric acid. In general, a minimum of 500 pollen grains of trees and shrubs (arboreal pollen $=$ AP) was counted in each sample, but in samples where their frequency was very low, all the pollen grains from the two slides $22 \times 22 \mathrm{~mm}^{2}$ were identified. The sum of arboreal and non-arboreal pollen was the basis of percentage calculation $(\mathrm{AP}+\mathrm{NAP}=100 \%)$.

The material for plant macrofossil analysis was composed of samples taken in 10-cm intervals, and the sample volume was $20 \mathrm{~cm}^{3}$. The material was rinsed with water onto sieves with mesh sizes of 0.25 and $0.5 \mathrm{~mm}$. The residue was identified under a stereoscopic microscope at a magnification of $10-100 \times$. One slide from each sample was examined under a microscope at $200-400 \times$ to determine the peat composition. Macrofossils were identified with the use of available guides (e.g. Katz et al., 1965, 1977; Berggren, 1968; Tobolski, 2000; Mauquoy \& van Geel, 2007).

Chironomid fossil analysis was performed according to the methods described by Brooks et al. (2007) using a $63-\mu \mathrm{m}$ mesh size sieve. In samples where a small number of head capsules were present, kerosene floatation on a bigger volume of sediment (up to $80 \mathrm{~cm}^{3}$ ) was used for the extraction of chironomid subfossils (Rolland \& Larocque, 2007). Head capsules were identified by using mainly the taxonomic keys by Wiederholm (1983), Klink \& Moller Pillot (2003) and Brooks et al. (2007). Water quality classification based on the proportions of tolerant and intolerant taxa follows Wilson and Ruse (2005). 
Numerical analyses and graphical presentation

Conventional radiocarbon dates were calibrated by using OxCal 4.05 (Bronk Ramsey, 2001) and the IntCal04 calibration curve (Reimer et al., 2004). Five-year smoothing was chosen for the calibration. Probability distributions for 10 calibrated dates were used for the estimation of an age-depth model. In addition, the calendar year 2006 was attributed to the top of the core. The age-depth model was built by using the P_Sequence deposition model procedure of OxCal 4.05 (Bronk Ramsey, 2008). Parameter $k$ of the P_Sequence function was set to 0.1 , and the interpolation parameter was set to 2 . The resulting expected values modelled for each dated depth were then interpolated by the Akima spline algorithm (Akima, 1970) to give the date for each centimetre of depth (Fig. 3). In addition, normalized probability distributions for each calibrated radiocarbon date used for age-depth modelling are also presented in Fig. 3. The grey shaded area in Fig. 3 represents the $68 \%$ probability range of the model.

For the summary diagram, general zones were delimited mainly on the basis of archaeological
Fig. 3 Age-depth model, (A) entire profile, (B) last 2,000 years
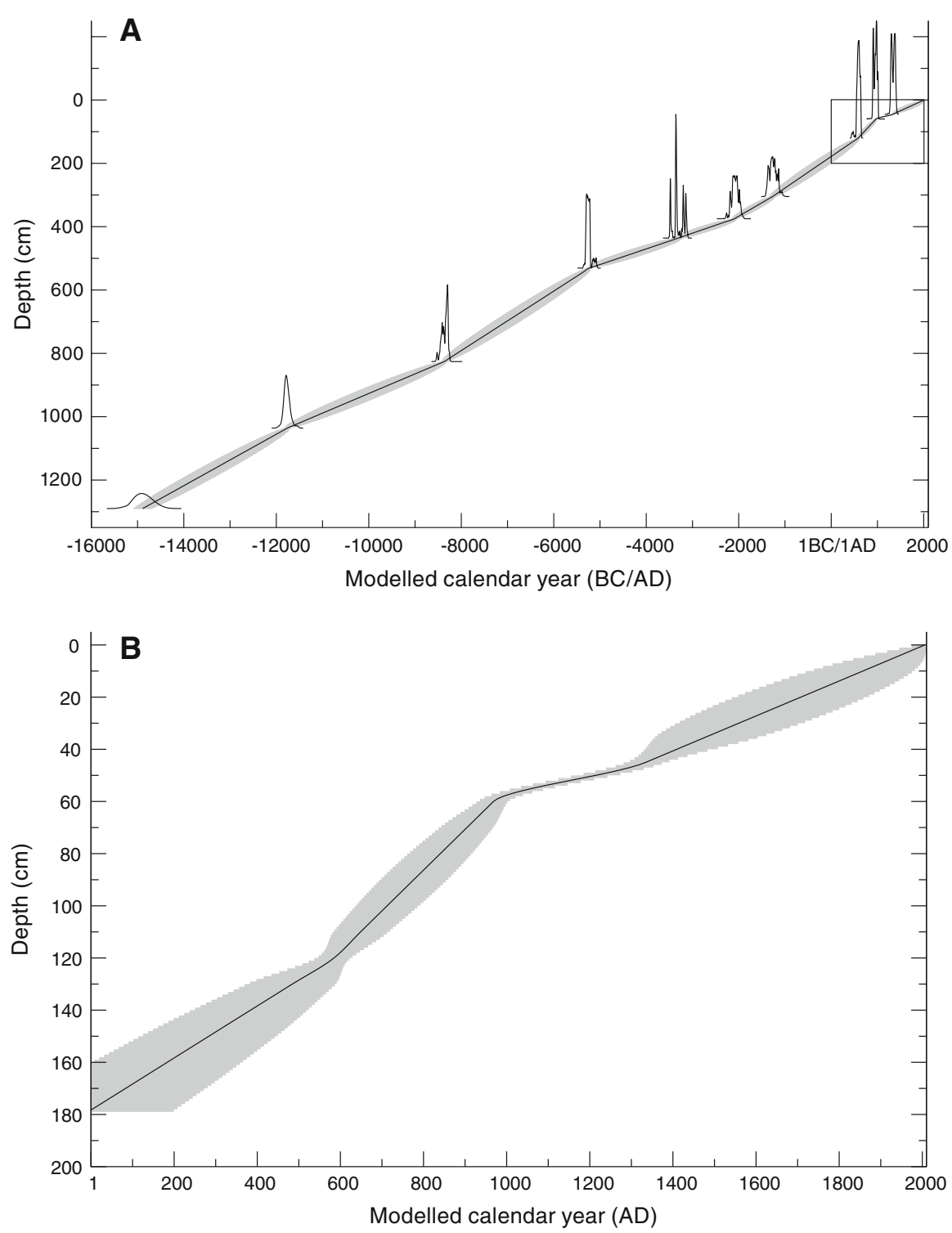
periods (Kaczanowski \& Kozłowski, 1998), but an additional zone Z6 was created because of a significant, abrupt change in all proxies.

In order to reconstruct quantitatively the water table and $\mathrm{pH}$ in the mire, we applied a training set consisting of 123 surface samples taken from natural Sphagnum mires in Pomerania (Lamentowicz \& Mitchell, 2005; Lamentowicz et al., 2008b), western Poland (Lamentowicz et al., 2008a) as well as in Żabieniec in 2005. In the publications mentioned above, the performance of four models was tested: partial least squares (PLS), weighted averaging (WA), tolerance down-weighted weighted averaging (WAtol) and weighted averaging partial least squares (WA-PLS), by using the program C2 (Juggins, 2003). The root mean square error of prediction (RMSEP) was calculated by using the jackknifing cross-validation procedure (Crowley, 1992). For depth to the water table (DWT) (range of modern samples $\min =-3 \mathrm{~cm} ; \quad \max =70 \mathrm{~cm}, \quad S D=14 \mathrm{~cm}$ ), the model with the lowest RMSEP was WAtol, with a maximum prediction bias of $8.9 \mathrm{~cm}$ and a jacknived root mean square error of prediction (RMSEP(jack)) of $4.3 \mathrm{~cm}$. For $\mathrm{pH}$, the model with the lowest RMSEP was WA-PLS (range of modern samples $\min =3.14$; $\max =7.27, \mathrm{SD}=1.11$ ), the maximum bias of the prediction was $0.5 \mathrm{pH}$ units and the RMSEP(jack) was $0.41 \mathrm{pH}$ units (Lamentowicz et al., 2008b; Lamentowicz \& Mitchell, 2005). Reconstruction of the general trophic status of the peatland was based on the quantitative $\mathrm{pH}$ reconstruction as well as qualitative attributes of testate amoebae and plant macrofossils data.

\section{Results}

Chronology and peat accumulation rates

The age-depth model presented in Fig. 3 shows that accumulation rate throughout the history of the peat bog was approximately constant. The average accumulation rate calculated by linear approximation of the age-depth model curve is about $0.74 \mathrm{~mm} /$ year. However, some small variations of accumulation rate can be observed. Small decreases in the accumulation rate during 12000-7000 $\mathrm{BC}$ and 5000-2000 BC as well as a small increase during $8000-5000$ BC are apparent.
Biological records

Proxies analyzed in this study allowed reconstructing the history of the peatland and its surroundings, spanning the last two millennia. Initially, we developed a zonation for each proxy. However, because zones for the particular proxies did not remain in agreement, we presented the development history in the context of human impact, which is a useful criterion from the point of view of the aim of this study. Low agreement between zonations might be caused by different resolution of sampling, especially in the case of pollen analysis.

Detailed diagrams of each proxy are presented in separate figures for plant macrofossils (Fig. 4), pollen (Fig. 5), chironomids (Fig. 6) and testate amoebae (Fig. 7).

A summary diagram with a short interpretation is presented in Fig. 8. The development history of the Żabieniec mire was divided into six stages (Z1-Z6) according to the archaeological periods.

History of the Żabieniec peatland

Roman Period, ca. O BC-AD 375 (Z1)

(Figs. 4, 5, 6, 7)

During this period, the Żabieniec peatland was a mesotrophic-telmatic habitat with shallow water, as indicated by brown mosses, Scheuchzeria palustris, Carex spp., and remains of Pediastrum and Botryococcus (Fig. 4-5). Between AD 100 and AD 200, Sphagnum spp. of the section Sphagnum became more abundant, whereas Scheuchzeria palustris and Cyperaceae declined, which suggests a temporal acidification (van Breemen, 1995; Tallis, 1983). At about $\mathrm{AD} 400$, the peatland became mesotrophic again, which was probably connected with a rise in the water table. All proxies show relatively stable hydrological conditions. Testate amoebae were absent. Human impact was insignificant, but infrequent pollen of Rumex acetosa, Plantago lanceolata and cereals (including Secale) shows human presence (Behre, 1981) in more distant areas.

Chironomid analysis indicates that Żabieniec in the Roman Period was a mire with a shallow water body overgrown with macrophytes. The dominant species was Paratendipes nudisquama. Paratendipes larvae often occur in small standing water bodies like 


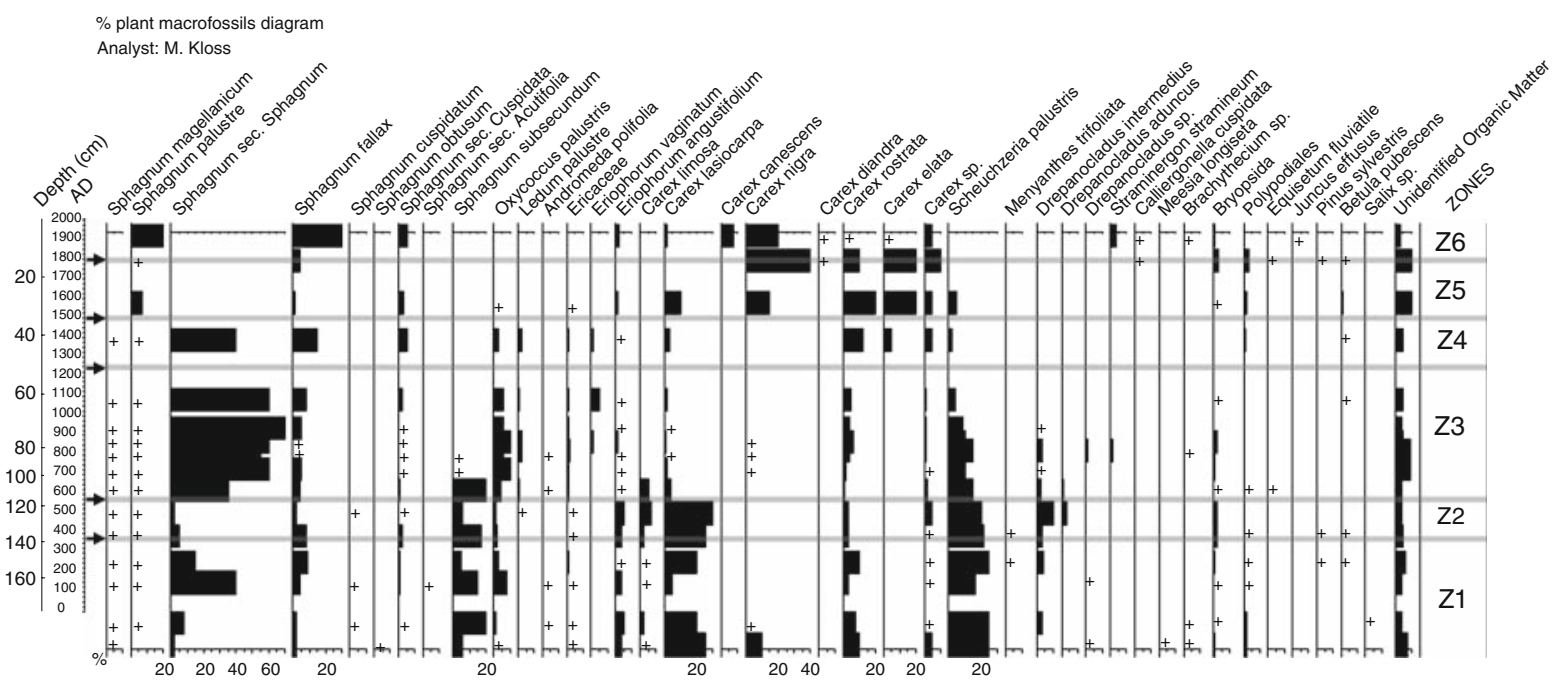

Fig. 4 Percentage plant macrofossil diagram. Zonation based on archaeological periods

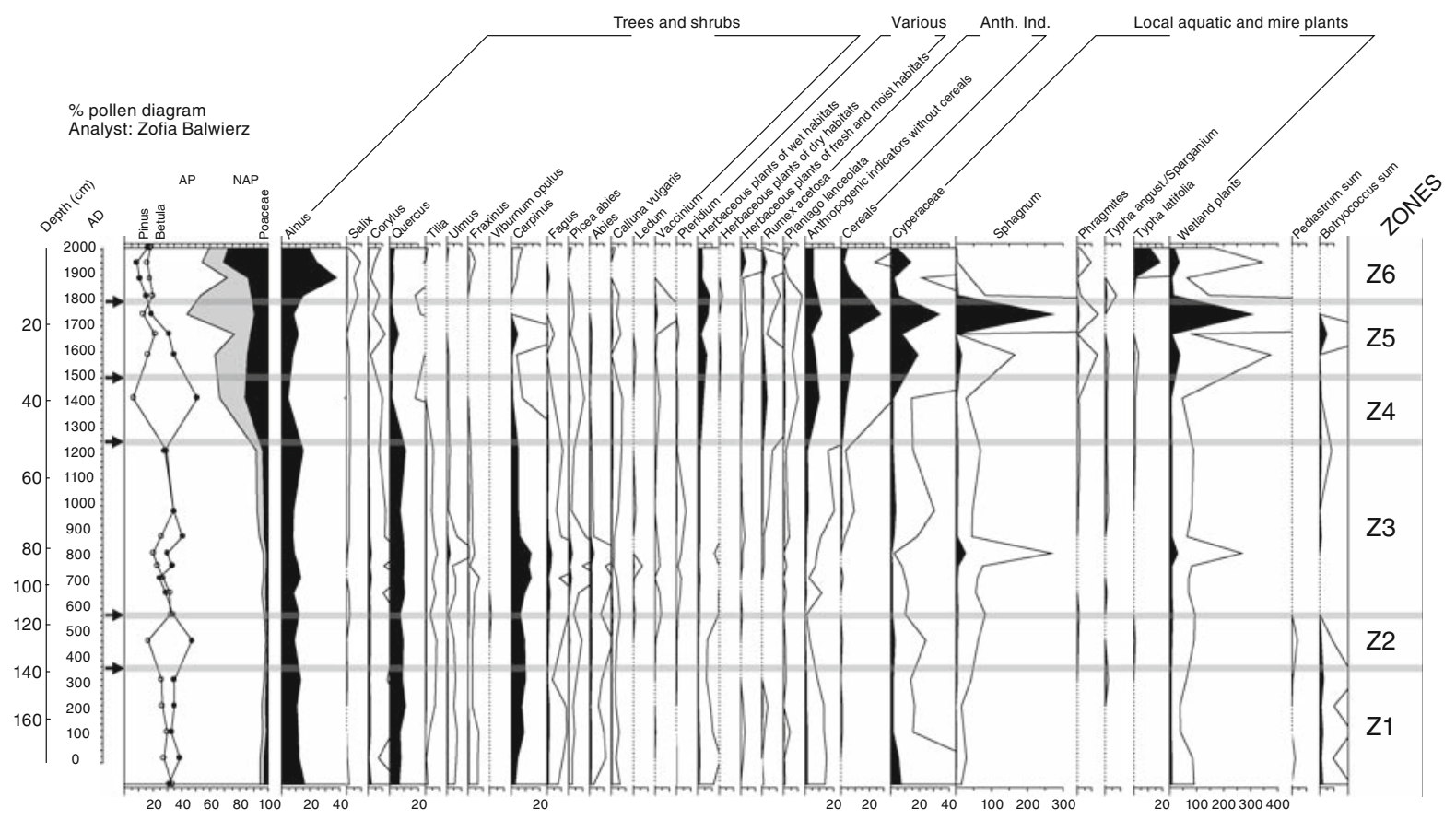

Fig. 5 Percentage pollen diagram. Zonation based on archaeological periods

ponds and bogs (Wiederholm, 1983). Chironomid communities were relatively rich in taxa, with high dominance of macrophyte-related taxa characteristic of small acid water bodies with dense vegetation such as Monopelopia tenuicalcar and Lauterborniella agrayloides (ecological preferences after Klink \& Moller Pillot (2003) and Vallenduuk \& Moller Pillot (2007)).
Migration period, ca. AD 375-568 (Z2)

(Figs. 4, 5, 6, 7)

This stage was characterized by indicators of wet and mesotrophic habitats. Scheuchzeria palustris and Carex spp. dominated among vascular plants. Pediastrum and Botryococcus increased, representing open water surface. There was no decline in AP. During this 


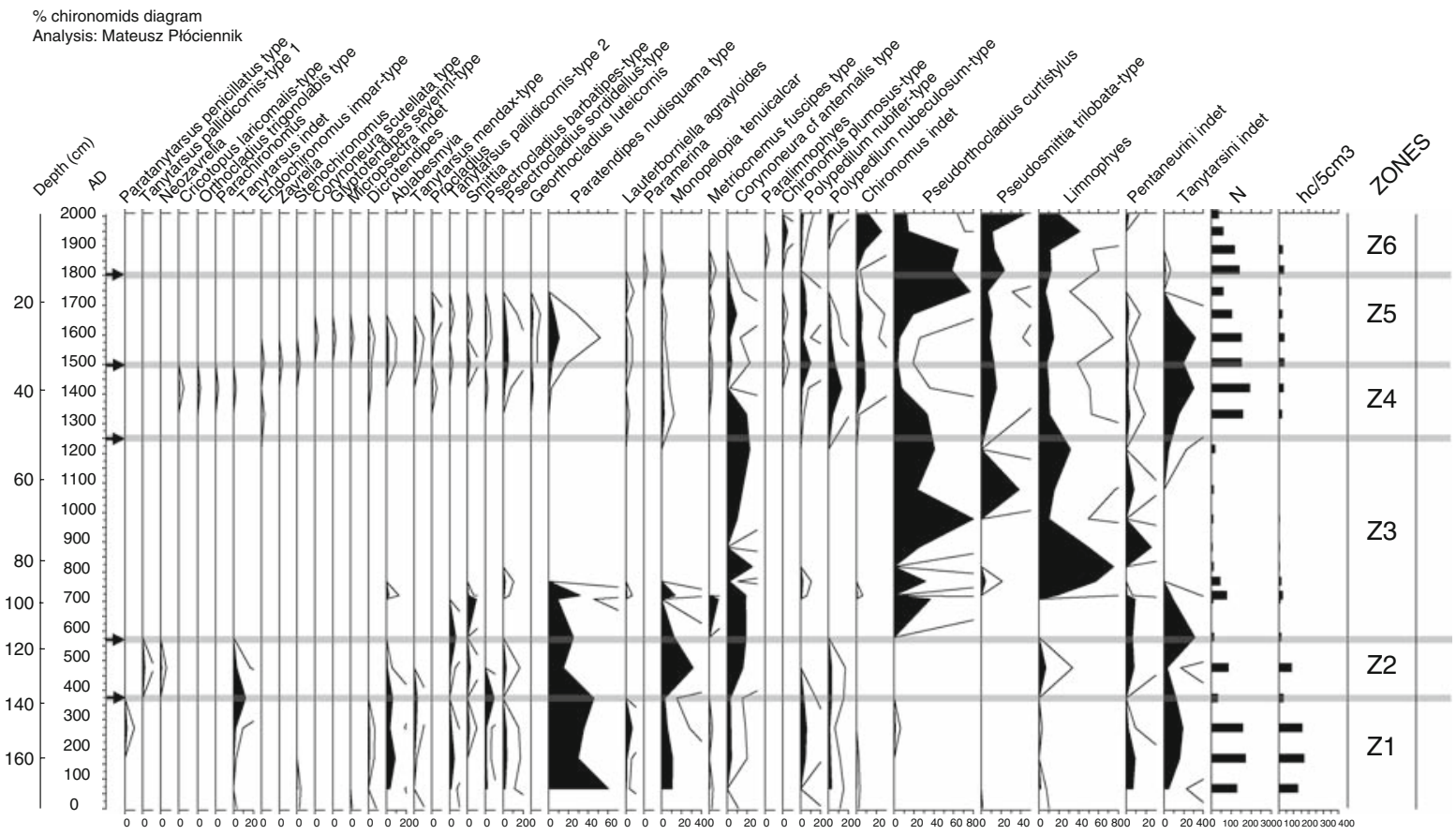

Fig. 6 Percentage chironomid diagram. Zonation based on archaeological periods

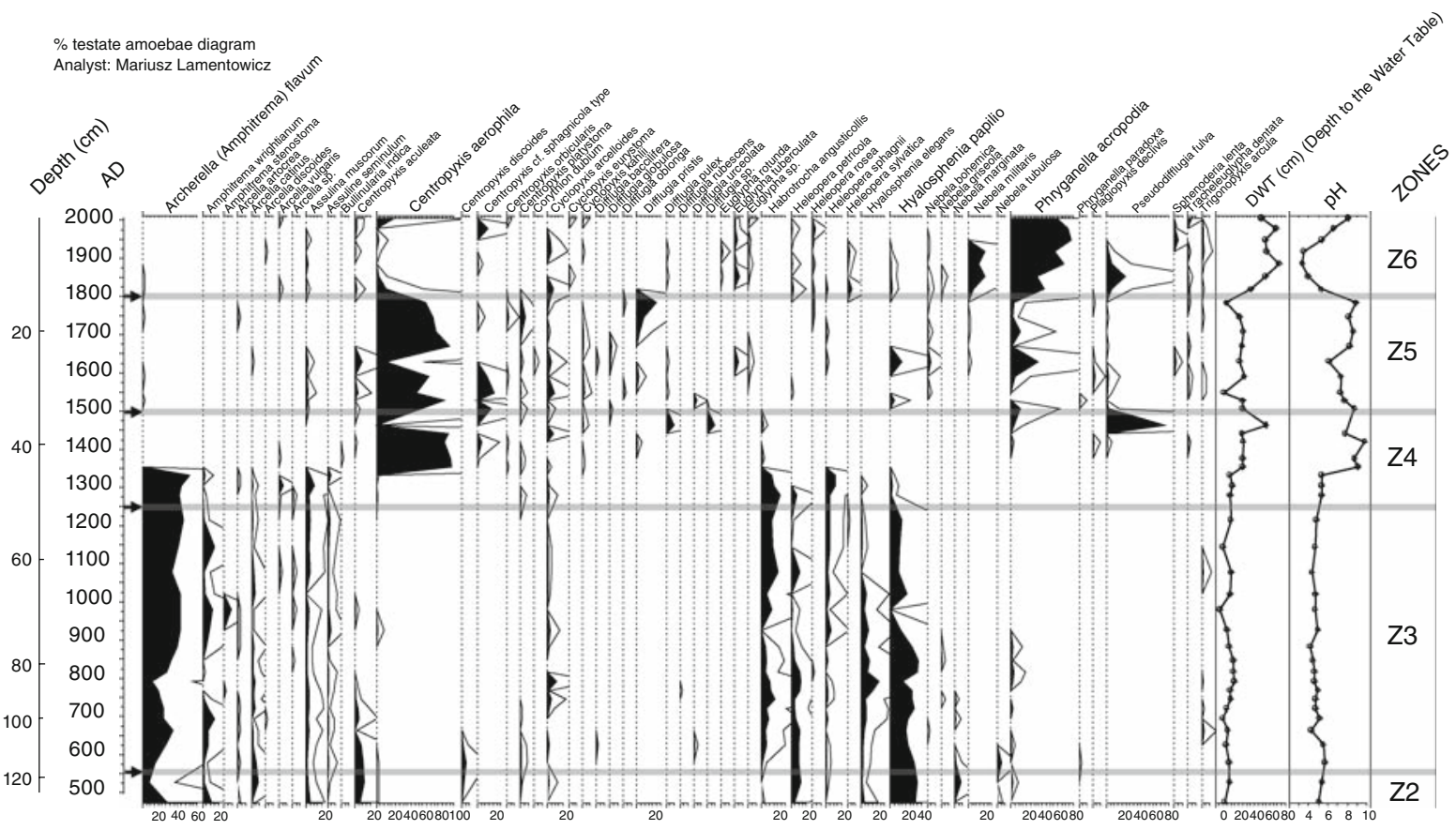

Fig. 7 Percentage testate amoebae diagram. Zonation based on archaeological periods

stage (AD 500), the first testate amoebae appeared, mainly oligotrophic taxa (Lamentowicz \& Mitchell, 2005; Lamentowicz et al., 2008b) (Amphitrema wrightianum, Archerella (Amphitrema) flavum) and taxa typical for mesotrophic-telmatic conditions (Lamentowicz \& Mitchell, 2005; Lamentowicz et al., 


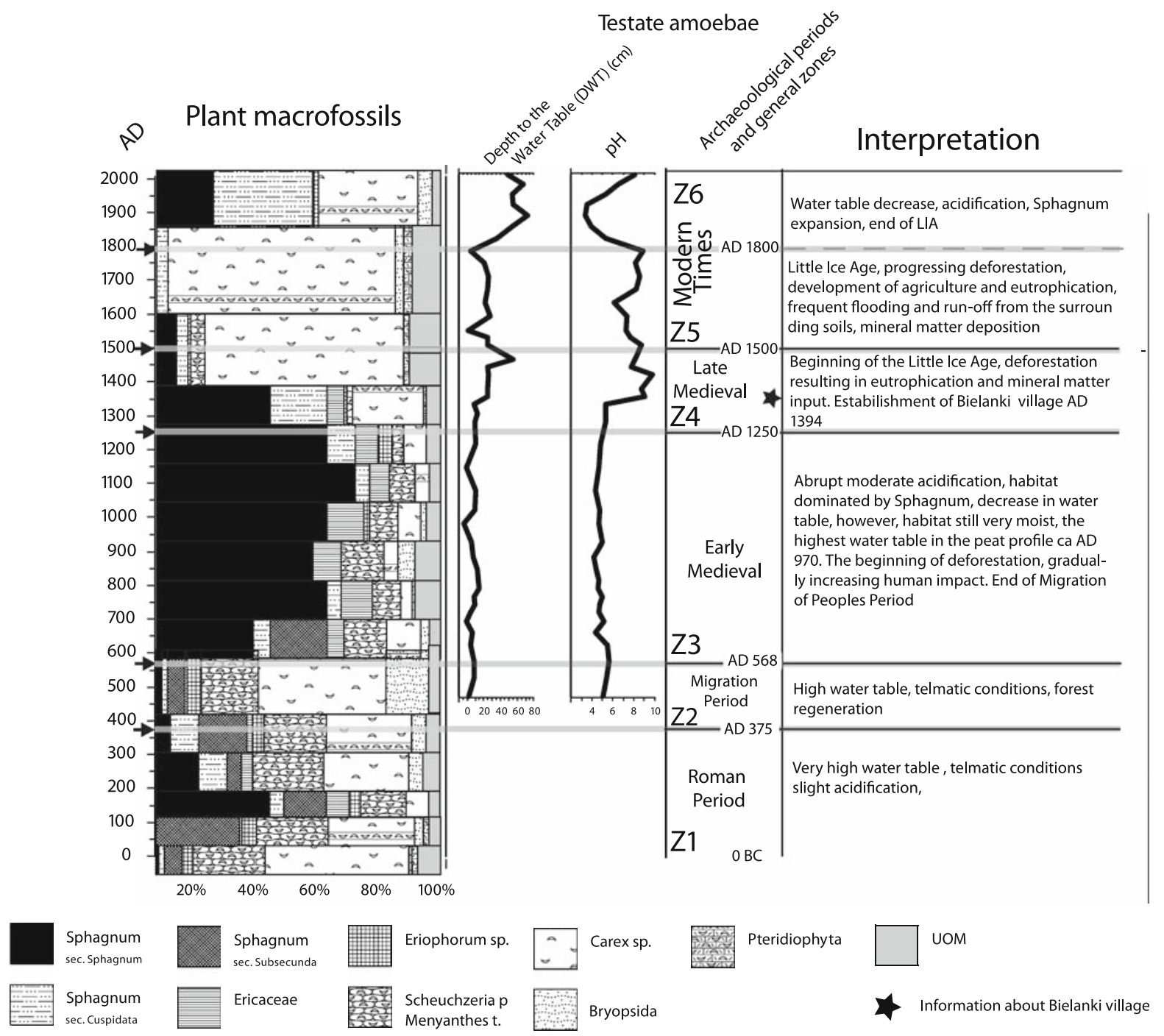

Fig. 8 Comparison of plant macrofossils data with quantitative reconstructions based on testate amoebae. Macrofossils show local habitat changes. Environmental variables from testate amoebae are based on regional transfer function. Other

2008b) (such as Centropyxis aculeata and C. discoides). Testate amoebae appeared abruptly, which suggests their rapid establishment. Their presence was connected with an increasing abundance of Sphagnum. The resolution of plant macrofossil analysis does not make it possible to determine the exact date of Sphagnum expansion, but remains of testate amoebae reveal that it was not a gradual process.

The composition of chironomid assemblages changed and diversity decreased, which indicates a proxies are summarized in the Results and Discussion sections. First information about location of Bielanki village is also mentioned and the zonation is based on Polish archaeological periods

shift in the ecosystem. The terrestrial Smittia appeared (Brooks et al., 2007), the domination of Paratendipes nudisquama decreased, while shares of some acidophilic taxa-Monopelopia tenuicalcar, Limnophyesbriefly increased. Furthermore, Corynoneura cf. antennalis increased; this species is usually associated with streams but frequent also in acidic waters (Klink \& Moller Pillot, 2003). Larvae in this morphotype in Żabieniec seem to be associated with acidic conditions. 
Early Medieval Period, ca. AD 568-1250 (Z3)

(Figs. 4, 5, 6, 7)

From ca. AD 600, oligotrophic Sphagnum peatland developed. This is roughly concurrent with the end of the Migration Period. However, during the entire Early Medieval Period, anthropogenic pollen indicators were low, but gradually increasing. There were no direct changes in the peatland surroundings, but distant transport of some pollen taxa (Rumex acetosa, Plantago lanceolata and cereals) represents the Early Medieval economy. Between $\mathrm{AD} 700$ and $\mathrm{AD}$ 850, Carpinus forest regenerated. Carpinus shows a constant decline since AD 850, along with an increase in pollen indicators of human activity. Furthermore, the proportion of NAP gradually increased, representing landscape openness. The testate amoebae assemblage was composed mainly of species characteristic for the moist Sphagnum lawn (Lamentowicz \& Mitchell, 2005; Lamentowicz et al., 2008b), e.g. Amphitrema flavum and Hyalosphenia papilio; however, an important moisture indicator Amphitrema wrightianum (Charman et al., 2000; Lamentowicz \& Mitchell, 2005; Lamentowicz et al., 2008b) shows wetter episodes during ca. AD 690, ca. AD 1000 and ca. AD 1150. Reconstructed values of depth to the water table fluctuate between 0 and $20 \mathrm{~cm}$. Average $\mathrm{pH}$ was around 4.5. These stable hydrological conditions in the peatland were maintained until ca. AD 1350.

From ca. AD 750 to ca. AD 1250, only four chironomid taxa were present. The abundance of larve was low from ca. AD 750 to ca. AD 1200, which may indicate water table decrease and Sphagnum expansion. A rapid decline and disappearance of nearly all shallow-water taxa (including Paratendipes nudisquama) up to $\mathrm{AD} 750$ and their replacement by semiterrestrial ones tolerant to low $\mathrm{pH}$ such as Pseudorthocladius curtistylus and Limnophyes (Klink \& Moller Pillot, 2003; Brooks et al., 2007), may indicate semiterrestrial conditions and coincide with those having a $\mathrm{pH}$ below 5.0 as inferred by testate amoebae (Fig. 8). Only the percentage of Corynoneura cf. antennalis increased. This species is not a terrestrial one (Klink \& Moller Pillot, 2003) which suggests the presence of at least temporally open water table on the mire surface.
Late Medieval Period, AD 1250-1500 (Z4)

(Figs. 4, 5, 6, 7)

Historically, year ca. AD 1250 marks the end of the Early Medieval Period, but the most important transition in the peatland record is dated to ca. AD 1350. Up to this date, conditions were relatively stable, with rapid peat accumulation by Sphagnum. The beginning of the Late Medieval Period is marked by ca. AD 1250, and the probable deforestation in the immediate vicinity of the Żabieniec mire is marked by ca. AD 1350, which might have triggered a change in the Żabieniec peatland vegetation and peat composition. The closeness of the deforestation can be estimated indirectly by testate amoebae and chironomids, as the pollen record possesses a lower sampling resolution. Peat-forming vegetation became dominated by Cyperaceae, indicating habitat eutrophication (Fig. 8). The curve of depth to the water table shows a decrease in the water table, with the lowest value ca. AD 1450, but $\mathrm{pH}$ increased to unusual value $(>9)$. This very high $\mathrm{pH}$ value is hard to explain; it may be caused by the co-occurrence of minerotrophic indicators in fossil testate amoebae data. However, it reveals the instability of the peatland ecosystem, caused by change in the surroundings. Pollen data show an increase in human impact and NAP percentage, and a decline in pollen of all trees. Furthermore, an increase of anthropogenic indicators is apparent, e.g. of cereals, Rumex acetosa and Plantago lanceolata. Remains of Botryococcus represent increased wetness. However, this peak is visible in only one sample. This wet shift is also reflected in the $\mathrm{pH}$ curve, representing eutrophication. Testate amoebae show a dramatic change in the community composition. Centropyxis aerophila reached abundances over $90 \%$ from ca. AD 1350 when the peat consisted of mineral matter, whereas before ca. AD 1350, nearly no mineral particles were recorded in the peat. Most testate amoebae occurring during this phase represent the genera Centropyxis, Cyclopyxis and Difflugia. At about AD 1400, the highest value of $\mathrm{pH}$ was recorded. The presence of Phryganella acropodia indicates short dry shifts (Mitchell et al. 2001).

Non-biting midges also revealed a sudden shift in the mire in the Late Medieval Period, associated with human influence on the bog. Human impact increased the abundance and diversity of chironomid 
communities, with the maximum ca. AD 1510. Most of the 31 taxa from the Late Medieval Period were represented also in the Roman Period and during the Migration Period. The factors that seemed to have determined the composition of assemblages in this period were $\mathrm{pH}$ and moderate eutrophication. Also, the water level was higher than that in the Early Medieval Period, which was crucial for the existence of rich assemblages of littoral species and decreased the dominance of terrestrial ones. While semiterrestrial taxa typical for acidified habitats (e.g. Pseudorthocladius curtistylus) and Corynoneura cf. antennalis were less abundant, others considered as eurytopic, occurring in neutral waters (Klink \& Moller Pillot, 2003; Brooks et al., 2007) (Psectrocladius sordidellus-type, Dicrotendipes, Polypedilum nubeculosum-type) were more abundant. Lower percentage of intolerant taxa (following the classification in Wilson \& Ruse, 2005) than that in the Roman Period indicates higher trophy coinciding with higher $\mathrm{pH}$ inferred from testate amoebae.

Modern period, ca. AD 1500-1800 (Z5)

(Figs. 4, 5, 6, 7)

During this phase, the decline in NAP and the increase in anthropogenic indicators continued. Local vegetation remained dominated by Cyperaceae, with an even lower percentage of Sphagnum. Cereals reached over $30 \%$ of the total pollen during ca. $\mathrm{AD}$ 1750 , and such high percentages should be interpreted as indicating the cultivation in the direct surroundings of the peatland. The landscape became more and more open, as all tree taxa declined in abundance through the interval. Macrofossils and pollen of wetland plants, including Botryococcus, indicate shallow water conditions. Also, testate amoebae reveal a high water table and high $\mathrm{pH}$. Centropyxis aerophila was accompanied by other species present at lower abundance, e.g. Centropyxis cf. sphagnicola type, C. platystoma, Cyclopyxis arcelloides and Phryganella acropodia.

Abundant chironomid assemblages existed to AD 1670, whereas later only 10 mainly acidophilic and terrestrial ones remained. The percentage of Pseudorthocladius curtistylus sharply increased during ca. AD 1700, indicating the return of the mire habitat to conditions preceding human influence on the mire in the Late Medieval Period.
Modern period, ca. AD 1800-2006 (Z6)

(Figs. 4, 5, 6, 7)

The last phase of Żabieniec mire development is characterized by the reappearance of Sphagnum, afforestation and an abrupt increase in Alnus. Human indicators and cereals slightly decreased. From ca. AD 1800, a second complete transformation of the habitat took place. Among testate amoebae, Phryganella acropodia, which prefers dry conditions, reached a very high percentage $(>70 \%)$. This reflects a decrease in the water table. Also, Nebela militaris, a good dry indicator according to the existing transfer function of Lamentowicz et al. (2008c), confirmed this dry shift. Typha latifolia appeared during ca. AD 1900 in the peatland margins and has persisted there up to the present days.

Chironomids reveal a similar successional shift from the aquatic to terrestrial environment. Disappearance of nearly all littoral taxa and the dominance of Pseudorthocladius curtistylus, later also the terrestrial taxa Pseudosmittia trilobata-type and Limnophyes (Klink \& Moller Pillot, 2003), may indicate a low water level and terrestrial character of the bog. Polypedilum and Chironomus, which occur in samples from ca. AD 1890-2006, may indicate at least temporary water pools on the mire in the last century of the Żabieniec history, as these taxa are eurytopic and not terrestrial (Brooks et al., 2007). The number of head capsules was at first higher than those in the previous sections, but later it declined. Diversity of the assemblages decreased to ca. AD 1890 as well, and then slightly increased.

Archaeological data

In the immediate vicinity of the Żabieniec mire, only one archaeological site was discovered during an archaeological surface survey (Fig. 1D). It is the site Syberia Dolna no. 1, located ca. $350 \mathrm{~m}$ north of the mire, on the surface of a western slope of a dry valley. Results of an archaeological study in 2007 did not confirm the occurrence of any relics at this site. In the area of $150 \mathrm{~km}^{2}$, in the surroundings of the mire, 84 archaeological sites (with 119 archaeological relics) have been registered. Half of them date to the Late Medieval Period and Modern Period, and only five to the Early Medieval Period (not earlier than the eleventh century). In the group of 13 
prehistoric sites, five date to the Mesolithic, two to the Mesolithic or the Neolithic, 13 to the Bronze Age, seven to the Late Bronze Age/Early Iron Age, one to the Early Iron Age (Hallstatt Period), one to the Hallstatt Period/La Tene Period and 10 to the Roman period. Most of these were documented by few archaeological relics. The sites are located mainly in or near valleys of the rivers Mroga and Mrożyca. Most of the sites are up to $5 \mathrm{~km}$ away from the mire (AZP, unpublished data).

In the area of the Żabieniec village and of the nearby Bielanki village, we uncovered only few fragments of pottery during an intensive surface survey, dated to the Modern Period and probably to the Late Medieval. In the same area, we recorded the highest quantity of phosphorus in the ground, detected by a field method in the surface layer (90-100-cm thick). Simultaneously, in preliminary archaeological excavations, no evidence of human activity was found. The oldest historical sources were recorded in the close vicinity of the Żabieniec mire two villages, Kołacinek and Bielanki. Both were noted in the Early Middle AgesBielanki in 1394 (in Księgi Łęczyckie), and Kołacinek in 1257 and 1334 as the Kuyavian Duke's possessions. In the sixteenth century, the former village existed within the borders of the Brzeziny parish as Bylanowo and in 1576 as Bilianovo (noblemen's possessions). In records from the nineteenth century, we can find the name Bielanki. In the sixteenth century, Kołacinek was found among noblemen's possessions as well (Zajączkowski \& Zajączkowski, 1966).

The nineteenth century cartographic sources (i.e. Gilly's Map 1803 and the so-called Topographic Map of the Polish Kingdom 1839) show continuous woodlands in the surroundings of Żabieniec. In the late nineteenth century (according to Gilly's Map), we can find open areas only in proximity to the rivers Mroga and Mrożyca, near the village Wola Cyrusowa (north of Żabieniec), and probably in the vicinity of Bielanki. The Żabieniec village was present in AD 1825. The Topographic Map of the Polish Kingdom presents the increasing deforestation in the first half of the nineteenth century, in the surroundings of Bielanki as well. The Żabieniec mire was still forested at that time.

In the nineteenth century, in the area of the Brzeziny district, most arable land was moderately fertile, suitable for growing rye and potatoes. In this region, the extensive woodlands were administered or possessed by the state. In 1820-1853, the forest area declined in this region by ca. $30 \%$. In 1820 , woodlands occupied $40 \%$ of the district area, and in 1853 , only 28\% (Ohryzko-Włodarska, 1972).

Based on the results of former (AZP, unpublished data) and our archaeological field research, we can conclude that the human impact near the Żabieniec mire was insignificant almost until just prior to the Modern Period. Only a few relics, which are uncovered by archaeological research and dated to the Late Medieval Period, have been discovered. Older settlements occupied the areas close to the Mroga and Mrożyca river valleys.

\section{Discussion}

The multiproxy approach to the study of the Żabieniec peat archive allowed us to look at many aspects of the past change of the peatland and the surrounding landscape. This site may be regarded as an important reference point for higher resolution studies. All proxies give a very clear and sharp signal of abrupt changes in the peatland ecosystem and its surroundings. Two main questions arose during the investigation: (1) How and when did the anthropogenic land-use change affect the autogenic processes, and (2) How did the climate modify human activities and the natural signal provided by proxies?

Land-use change and autogenic processes

Our study shows that the direct human impact appeared in the Late Medieval Period, although settlements existed in the Bronze Age and the Iron Age in the nearby river valleys of Mroga and Mrożyca. Only one archaeological site was discovered in the immediate neighbourhood of the mire. Despite the late human influences, the peatland ecosystem completely changed since ca. AD 1350 together with the transformation of the landscape.

The Żabieniec mire is a classical example of plant succession in a former lake, which has progressed since the Late Glacial. In our study, we concentrated on the last stages of the terrestrialization process. During most of its history, this site was not directly disturbed by human activity. Human impact began to affect the peatland ecosystem quite recently. Deforestation and development of agriculture may lead to various trophic states and various types of vegetation. 
One very important study was realized on floating bogs of southern Ontario by Warner et al. (1989). These authors showed an influence of deforestations on peatland ecosystems (water table fluctuations and vegetation change). Magyari et al. (2001) also interpreted the transition to higher mire water table as at least partly induced by gradually intensifying human activity in northeastern Hungary. The authors state that the periodic supply of nutrients together with human-induced water table increases may have delayed the autogenic succession. Other example of human impact to peatlands (vegetation change) was provided by Rybníček and Rybníčková (1974).

What is more important is that we can incorrectly believe that present peatland systems are on their natural path of development (Warner, 1996). The Żabieniec peatland (and possibly most other peatlands in central Poland) represents altered ecosystems, disturbed in the past by, e.g. draining, agriculture and exploitation. However, past deforestation has been an underestimated factor, because no precise palaeoenvironmental data of the recent peat deposits are available for most of the sites.

The habitat in Żabieniec was very wet and telmatic until ca. AD 600. Then, the water table decreased and the site transformed into a Sphagnum-dominated mire. This drying took place during the Early Medieval Period and might be interpreted as a decrease in the water table leading to oligotrophication.

The strongest evidence for the gradual increase in Human impact on the region was post-AD 1350 deforestation (beginning of the Late Medieval Period). Consequently, run-off and aeolian transport from exposed soils caused eutrophication which can be tracked through changes in $\mathrm{pH}$. Geochemical results (increased values of magnesium, iron, potassium, zinc, as well as decrease of organic matter) obtained from the same core (Borówka et al., unpublished data) confirm our assumptions of soil erosion. Furthermore, chironomids and testate amoebae also clearly responded to the change in $\mathrm{AD} 1350$. Centropyxis aerophila domination indicates minerotrophic conditions. The shell morphology of this taxon allows living in mineral soil (Foissner, 1987, 2000); therefore, its dominance can be an indicator of mineral deposition on a peatland surface. The date of ca. AD 1350 may be connected with the first mention about the Bielanki village in AD 1394 when forest exploitation became more intensive in the direct vicinity of the mire.
Openness increased considerably through the Late Medieval and Modern Periods. During these periods, intensive development of agriculture was observed in central Poland, mainly in uplands (Twardy, 2008).

Other Polish studies of the recent peat cover (past 1-3 millennia) show how multidirectional peatland development can result in the development of different types of peatlands. One study from the Tuchola Forest (Lamentowicz et al., 2007) revealed an opposite (to the present study) response of peatland ecosystem to deforestations. In that case, forest cutting resulted in acidification and Sphagnum expansion during the last 200 years. This kettle-hole peatland is located in a sandy outwash plain covered by pine forest, where run-off from the acid soils led to pH decrease, which promoted Sphagnum establishment. Human impact appeared much later in this peatland than in the Żabieniec mire. Unfortunately, there is a shortage of high-resolution studies from this part of Europe to compare with the results from Żabieniec.

Climate-human or autogenic change?

Despite very pronounced human impact, it is probable that the Żabieniec peatland has also responded to climatic change. Until AD 600, the peatland was very wet, and then Sphagnum expanded (testate amoebae also increase rapidly in abundance at this time). This could have been a result of autogenic tendencies of the peatland to oligotrophication (Zobel, 1988) or of a decrease in the water table, caused by climatic change (Hughes \& Barber, 2003, 2004). The location of this peatland in an area of continental climate influences suggests that temperature might be the most important parameter governing the peatland hydrology (Schoning et al., 2005; Charman, 2007), and the increase in temperature during the Medieval Warm Period may have influenced the water table. At present, the surface of the Żabieniec mire is flooded in wet years. Our proxies show that such flooding occurred also in the past. A good example for comparison is the previously mentioned kettle-hole peatland in Tuchola (Lamentowicz et al., 2008b), where such flooding took place in the past and is still observed today. However, the pattern of changes in Tuchola is different, as this mire acidified much earlier, ca. 5000 BP. In the case of kettle holes such as the ones in Żabieniec and Tuchola, acidification is not a synonym 
of ombrotrophication and it may have depended on soil leaching during the Holocene.

We suggest that during most of the history of Żabieniec, climate was a very important factor, but the signal was more recognizable as terrestrialization progressed. The dry shift during ca. AD 600 and relatively stable hydrological conditions were probably related to climate. However, this was too early for the Medieval Warm Period (which is usually dated to AD 800-1300), although during this time also, many other areas of the world experienced drought episodes (Bradley et al., 2003). Nevertheless, it is possible that in this part of Europe, the situation was different, and the Medieval Warm Period started earlier. Having no data from this part of Poland, we can compare our results with those obtained from northern Poland, from a Baltic bog in Stążki (Lamentowicz et al., 2009). At this site, the water table remained high until AD 1000-1100, and later, it decreased and became very unstable. The last part of the Early Medieval Age and the Late Medieval Age were very dry at Stążki, and this multiproxy study shows that at the beginning of the Little Ice Age, the record of climate change may have been modified human impact.

In the case of Żabieniec, intensified human impact was synchronous with that of the Little Ice Age (LIA). This causes difficulties in identifying the climate signal. Pronounced human impact occurs during the LIA, which is dated differently in various parts of the world. The LIA was recorded in many environmental archives in Europe (Mauquoy et al., 2002; Matthews, 2005; Weckström et al., 2006; Blass et al., 2007; van der Linden et al., 2008), and it is commonly dated to AD 1550-1850 (Bradley \& Jones, 1992). In Poland, this important event is not well documented, but records of it may be more common than we suppose. A comparison of our wet shift dated to ca. $1350 \mathrm{AD}$ can also be made with other European data such as those of Magny (2004) for central Europe, who dates a final phase of lake level increase to AD 1394.

The major hydrological shift at Żabieniec at AD 1350 corresponds to the Wolf minimum, suggesting that the shift was in response to reduced solar activity. The impact of the Maunder minimum (Shindell et al., 2001) is well documented because all proxies show that a very wet period occurred between AD 1500 and AD 1800. It is possible that climate was the decisive factor for human settlement in the vicinity of Żabieniec that is located on the morainic plateau. Formerly, settlements were only recorded in the river valleys. Due to the increase in wetland areas, people may have been forced to search for more suitable places for colonization.

The openness of the vegetation significantly increased in the period AD 1800-2006, which is well documented in the historical sources, but the water table decreased in the peatland. This intriguing dry shift may be interpreted as the end of the Little Ice Age. Until the early twentieth century, no peatland exploitation took place which indicates that any changes in the peatland were due to climate variability. This also confirms that not only did deforestation influence the water table in the peatland, but also that climate played a crucial role in the past. We excluded autogenic change as the reason of water table decrease because there are no Sphagnum hummocks in the mire surface. At present, Sphagnum fallax dominates in the moss layer. This species tolerates a very wide range of trophic conditions, and even a high input of phosphorus may not be disturbing (Limpens et al., 2003).

Acknowledgements The study was supported by a grant from the Polish Ministry of Science and Higher Education, No. 2P04E02228, 'Changes in the Environment of the Łódź Hills (Wzniesienia Łódzkie) during the Vistulian (Weichselian) and Holocene in the light of interdisciplinary palaeoecological research of the Żabieniec mire' (Principal Investigator: Jacek Forysiak). Mariusz Lamentowicz's activity was funded by the above-mentioned grant, as well as, a second grant from the Polish Ministry of Science and Higher Education, No. 2PO4G03228, 'Climatic changes in Pomerania (northwestern Poland) in the last millennium, based on the multiproxy highresolution studies'. We thank Milena Obremska for her help in pollen diagram preparation and Sylwia Ufnalska for improving the English language. We also thank the three anonymous referees for their valuable comments.

\section{References}

Akima, H., 1970. A new method of interpolation and smooth curve fitting based on local procedures. Journal of the Association for Computing Machinery 17: 589-602.

Amesbury, M. J., D. J. Charman, R. M. Fyfe, P. G. Langdon \& S. West, 2008. Bronze Age upland settlement decline in southwest England: testing the climate change hypothesis. Journal of Archaeological Science 35: 87-98.

Arrhennius, O., 1950. Főrhistorisk bebyggeise antydd genom kemisk analys. Fornvännen 45: 59-62.

Behre, K. E., 1981. The interpretation of anthopogenic indicators in pollen diagrams. Pollen and Spores 23: 225-245.

Berggren, G., 1968. Atlas of Seeds and Fruits of NorthEuropean Plant Species (Sweden, Norway, Denmark, East Fennoscandia and Iceland) with Morphological 
Descriptions. Part 2, Cyperaceae. Swedish Natural Science Research Council, Stockholm.

Berglund, B. E. \& M. Ralska-Jasiewiczowa, 1986. Pollen analysis and pollen diagrams. In Berglund, B. E. (ed.), Handbook of Holocene Paleoecology and Paleohydrology. Wiley, Chichester-Toronto: 455-484.

Blackford, J., 1993. Peat bogs as sources of proxy climatic data: past approaches and future research. In Chambers, F. M. (ed.), Climate Change and Human Impact on the Landscape. Chapman and Hall, New York: 47-56.

Blass, A., M. Grosjean, A. Troxler \& M. Sturm, 2007. How stable are twentieth-century calibration models? A highresolution summer temperature reconstruction for the eastern Swiss Alps back to AD 1580 derived from proglacial varved sediments. The Holocene 17: 51-63.

Blundell, A., D. J. Charman \& K. Barber, 2008. Multiproxy late Holocene peat records from Ireland: Towards a regional palaeoclimate curve. Journal of Quaternary Science 23: 59-71.

Booth, R. K., M. Notaro, S. T. Jackson \& J. E. Kutzbach, 2006. Widespread drought episodes in the western Great Lakes region during the past 2000 years: Geographic extent and potential mechanisms. Earth and Planetary Science Letters 242: 415-427.

Bradley, R. S. \& P. D. Jones, 1992. When was the "Little Ice Age"? In Mikami, T. (ed.), International Symposium on the Little Ice Age Climate. Tokyo Metropolitan University, Tokyo, Japan: 1-4.

Bradley, R. S., K. R. Briffa, J. E. Cole, M. K. Hughes \& T. J. Osborn, 2003. The Climate of the Last Millennium. In Alverson, K., R. Bradley \& T. Pedersen (eds.), Paleoclimate, Global Change, and the Future. Springer-Verlag, Berlin, Heidelberg, New York: 105-142.

Bragg, O. M., 2002. Hydrology and peat-forming wetlands in Scotland. The Science of the Total Environment 294: 111-129.

Bronk Ramsey, C., 2001. Development of the Radiocarbon Program OxCal. Radiocarbon 43: 355-363.

Bronk Ramsey, C., 2008. Deposition models for chronological records. Quaternary Science Reviews 27(1-2): 42-60. doi:10.1016/j.quascirev.2007.01.019.

Brooks, S. J., P. G. Langdon \& O. Heiri, 2007. The identification and use of Palaearctic chironomidae larvae in palaeoecology. QRA Technical Guide No. 10. Quaternary Research Association, London.

Chambers, F. M. \& D. J. Charman, 2004. Holocene environmental change: contributions from the peatland archive. The Holocene 14: 1-6.

Chambers, F. M., D. Mauquoy, S. A. Brain, M. Blaauw \& J. R. G. Daniell, 2007. Globally synchronous climate change 2800 years ago: proxy data from peat in South America. Earth and Planetary Science Letters 253: 439-444.

Charman, D. J., 2002. Peatlands and Environmental Change. Wiley, Chichester: $301 \mathrm{pp}$.

Charman, D. J., 2007. Summer water deficit variability controls on peatland water-table changes: implications for Holocene palaeoclimate reconstructions. The Holocene 17: 217-227.

Charman, D. \& A. Blundell, 2007. A new European testate amoebae transfer function for palaeohydrological reconstruction on ombrotrophic peatlands. Journal of Quaternary Science 22: 209-221.
Charman, D. J., D. Hendon \& W. A. Woodland, 2000. The Identification of Testate Amoebae (Protozoa: Rhizopoda) in Peats. Technical Guide No. 9. Quaternary Research Association, London: $147 \mathrm{pp}$.

Clarke, K. J., 2003. Guide to Identification of Soil ProtozoaTestate Amoebae. Freshwater Biological Association, Ambleside: $40 \mathrm{pp}$.

Crowley, P. H., 1992. Resampling methods for data analysis in computation-intensive ecology and evolution. Annual Review of Ecology and Systematics 23: 405-447.

Eidt, R., 1973. A rapid chemical field test for archaeological site surveying. American Antiquity 38: 207-209.

Faegri, K. \& J. Iversen, 1989. Textbook of Pollen Analysis. Wiley, Chichester-Toronto.

Foissner, W., 1987. Soil protozoa: fundamental problems. Ecological significance, adaptations in ciliates and testaceans, bioindicators, and guide to literature. Progress in Protistology 2: 69-212.

Foissner, W., 2000. The Centropyxis aerophila complex (Protozoa: Testacea). Acta Protozoologica 39: 257-273.

Grospietsch, T., 1958. Wechseltierchen (Rhizopoden). Kosmos, Stuttgart: 1-86.

Hendon, D. \& D. J. Charman, 1997. The preparation of testate amoebae (Protozoa: Rhizopoda) samples from peat. The Holocene 7: 199-205.

Hughes, P. D. M. \& K. E. Barber, 2003. Mire development across the fen-bog transition on the Teifi floodplain at Tregaron Bog, Ceredigion, Wales, and a comparison with 13 other raised bogs. Journal of Ecology 91:253-264.

Hughes, P. D. M. \& K. E. Barber, 2004. Contrasting pathways to ombrotrophy in three raised bogs from Ireland and Cumbria, England. The Holocene 14: 65-77.

Hughes, P. D. M., S. H. Lomas-Clarke, J. Schulz \& P. Jones, 2007. The declining quality of late-Holocene ombrotrophic communities and the loss of Sphagnum austinii (Sull. ex Aust.) on raised bogs in Wales. The Holocene 17: 613-625.

Joosten, H. \& D. Clarke, 2002. Wise Use of Mires and Peatlands-Background and Principles Including a Framework for Decision-making. International Mire Conservation Group and International Peat Society, Saarijärvi.

Juggins, S., 2003. C2 User guide. Software for Ecological and Palaeoecological Data Analysis and Visualisation. University of Newcastle, Newcastle upon Tyne, UK: 69 pp.

Kaczanowski, P. \& J. K. Kozłowski, 1998. Great History of Poland, Vol. 1. The Oldest History of Poland Area (to VII Century). Fogra, Kraków: 382 pp.

Katz, N. J., S. V. Katz \& M. G. Kipiani, 1965. Atlas and Keys of Fruits and Seeds Occurring in the Quaternary Deposits of the USSR. Nauka, Moskva: 367 pp.

Katz, N. J., S. V. Katz \& E. I. Skobiejeva, 1977. Atlas of Macrofossils from Peats. Nedra, Moskva: 370 pp.

Klink, A. G. \& H. K. M. Moller Pillot, 2003. Chironomidae Larvae. Key to the Higher Taxa and Species of the Lowlands of Northwestern Europe 1.0 CD-ROM. ETI.

Kłysik, K., 2001. Climatic conditions. In Liszewski, S. (ed.), Monograph of Łódź Voivodeship. Łódzkie Towarzystwo Naukowe, Łódź. (in Polish).

Lagerback, R. \& A. N. N. M. Robertsson, 1988. Kettle holes: stratigrafical archives for Weichselian geology and 
palaeoenvironment in nothernmost Sweden. Boreas 17: 439-468.

Lamentowicz, M. \& E. A. D. Mitchell, 2005. The ecology of testate amoebae (Protists) in Sphagnum in north-western Poland in relation to peatland ecology. Microbial Ecology 50: 48-63.

Lamentowicz, M., K. Tobolski \& E. A. D. Mitchell, 2007. Palaeoecological evidence for anthropogenic acidification of a kettle-hole peatland in northern Poland. The Holocene 17: 1185-1196.

Lamentowicz, Ł., M. Lamentowicz \& M. Gąbka, 2008a. Testate amoebae ecology and a local transfer function from a peatland in western Poland. Wetlands 28: 164-175.

Lamentowicz, M., M. Obremska \& E. A. D. Mitchell, 2008b. Autogenic succession, land-use change, and climatic influences on the Holocene development of a kettle hole mire in Northern Poland (Northern Poland). Review of Palaeobotany \& Palynology 151: 21-40.

Lamentowicz, M., A. Cedro, G. Miotk-Szpiganowicz, E. A. D. Mitchell, J. Pawlyta \& T. Goslar, 2008c. Last millennium palaeoenvironmental changes from a Baltic bog (Poland) inferred from stable isotopes, pollen, plant macrofossils and testate amoebae Palaeogeography, Palaeoclimatology. Palaeoecology 265: 93-106.

Lamentowicz, M., K. Milecka, M. Gałka, A. Cedro, J. Pawlyta, N. Piotrowska, Ł. Lamentowicz \& W. O. van der Knaap, 2009. Climate- and human-induced hydrological change since AD 800 in an ombrotrophic mire in Pomerania (N Poland) tracked by testate amoebae, macro-fossils, pollen, and tree-rings of pine. Boreas 38: 214-229.

Limpens, J., B. M. Hilde \& F. Berendse, 2003. Expansion of Sphagnum fallax in bogs: striking the balance between $\mathrm{N}$ and $\mathrm{P}$ availability. Journal of Bryology 25: 83-90.

Magny, M., 2004. Holocene climate variability as reflected by mid-European lake-level fluctuations and its probable impact on prehistoric human settlements. Quaternary International 113: 65-79.

Magyari, E., P. Sumegi, M. Braun, G. Jakab \& M. Molnar, 2001. Retarded wetland succession: anthropogenic and climatic signals in a Holocene peat bog profile from northeast Hungary. Journal of Ecology 89: 1019-1032.

Matthews, J. A., 2005. 'Little Ice Age' glacier variations in Jotunheimen, southern Norway: a study in regionally controlled lichenometric dating of recessional moraines with implications for climate and lichen growth rates. The Holocene 15: 1-19.

Mauquoy, D. \& B. van Geel, 2007. Mire and Peat Macros. In A., E. S. (ed.), Vol. 3. p. 2315-2336, Elsevier.

Mauquoy, D., B. van Geel, M. Blaauw \& J. van der Plicht, 2002. Evidence from northwest European bogs shows 'Little Ice Age' climatic changes driven by variations in solar activity. The Holocene 12: 1-6.

Mitchell, E. A. D., 2003. Identification keys for testate amoebae. http://wslar.epfl.ch/mitchell/edward/Identification_ keys/Keys.htm.

Mitchell, E. A. D., W. O. van der Knaap, J. F. N. Leeuwen, A. Buttler, B. G. Warner \& J. M. Gobat, 2001. The palaeoecological history of the Praz-Rodet bog (Swiss Jura) based on pollen, plant macrofossils and testate amoebae (Protozoa). The Holocene 11: 65-80.
Ogden, C. G. \& R. H. Hedley, 1980. An Atlas of Freshwater Testate Amoebae. British Museum (Natural History) and Oxford University Press, (London and Oxford), London: $222 \mathrm{pp}$.

Ohryzko-Włodarska, C., 1972. Transformation of the Village of the Polish Kingdom in Years 1846-1870. An Example of Brzeziny District. Ludowa Spółdzielnia Wydawnicza, Warszawa: 364 pp. (in Polish).

Oksanen, P. O. \& M. Valiranta, 2006. Palsa mires in a changing climate. Suoseura 57: 33-43.

Ralska-Jasiewiczowa, M. \& M. Latałowa, 1996. Poland. In Berglund, B. E., H. J. B. Birks, M. Ralska-Jasiewiczowa \& H. E. Wright Jr (eds.), Palaeoecological Events During the Last 15000 years: Regional Syntheses of Palaeoecological Studies of Lakes and Mires in Europe. Wiley, Chichester: 403-472.

Ralska-Jasiewiczowa, M., M. Latałowa, K. Wasylikowa, K. Tobolski, T. Madeyska, H. E. Wright \& C. Turner Jr, 2004. Late Glacial and Holocene History of Vegetation in Poland Based on Isopollen Maps. W. Szafer Institute of Botany, Polish Academy of Sciences, Kraków.

Reimer, P. J., M. G. L. Baillie, E. Bard, A. Bayliss, J. W. Beck, C. J. H. Bertrand, P. G. Blackwell, C. E. Buck, G. S. Burr, K. B. Cutler, P. E. Damon, R. L. Edwards, R. G. Fairbanks, M. Friedrich, T. P. Guilderson, A. G. Hogg, K. A. Hughen, B. Kromer, G. McCormac, S. Manning, C. B. Ramsey, R. W. Reimer, S. Remmele, J. R. Southon, M. Stuiver, S. Talamo, F. Taylor, J. van der Plicht \& C. Weyhenmeyer, 2004. IntCal04 terrestrial radiocarbon age calibration, 0-26 cal kyr BP. Radiocarbon 46: 1029-1058.

Rolland, N. \& I. Larocque, 2007. The efficiency of kerosene flotation for extraction of chironomid head capsules from lake sediments samples. Journal of Paleolimnology 37: 565-572.

Rybníček, K. \& E. Rybníčková, 1974. The origin and development of waterlogged meadows in the central part of the Sumava Foothills. Folia Geobotanica \& Phytotaxonomica. 9: 45-70.

Rydin, H. \& J. Jeglum, 2006. The Biology of Peatlands. Oxford University Press, Oxford: $343 \mathrm{pp}$.

Schoning, K., D. J. Charman \& S. Wastegård, 2005. Reconstructed water tables from two ombrotrophic mires in eastern central Sweden compared with instrumental meteorological data. The Holocene 15: 111-118.

Shindell, D. T., G. A. Schmidt, M. E. Mann, D. Rind \& A. Waple, 2001. Solar forcing of regional climate change during the Maunder Minimum. Science 294: 2149-2152.

Sillasoo, Ü., D. Mauquoy, A. Blundell, D. Charman, M. Blaauw, J. R. G. Daniell, P. Toms, J. Newberry, F. M. Chambers \& E. Karofeld, 2007. Peat multi-proxy data from Männikjärve bog as indicators of late Holocene climate changes in Estonia. Boreas 36: 20-37.

Tallis, J. H., 1983. Changes in wetland communities. In Gore, A. J. P. (ed.), Mires: Swamp, Bog, Fen and Moor. Elsevier, Amsterdam: 311-347.

Tobolski, K. 2000. Przewodnik do oznaczania torfów i osadów jeziornych (A guide for identification of peat and lake sediments). Wydawnictwo Naukowe PWN, Warszawa, 508 pp.

Twardy, J., 2008. Transformacja rzeźby centralnej części Polski Środkowej w warunkach antropopresji. Transformation of 
the Relief of the Central Poland in Conditions of the Human Impact. Wydawnictwo Uniwersytetu Łódzkiego, Łódź. (in Polish).

Vallenduuk, H. J. \& H. K. M. Moller Pillot, 2007. Chironomidae Larvae of the Netherlands and Adjacent Lowlands. General Ecology and Tanypodinae. KNNV Publishing, Zeist, The Netherlands: 144 pp.

van Breemen, N., 1995. How Sphagnum bogs down other plants. Trends in Ecology and Evolution 10: 270-275.

van der Linden, M., J. Barke, E. Vickery, D. J. Charman \& B. van Geel, 2008. Late Holocene human impact and climate change recorded in a North Swedish peat deposit. Palaeogeography, Palaeoclimatology, Palaeoecology 258: 1-27.

Warner, B. G., 1993. Palaeoecology of floating bogs and landscape change in the Great Lakes drainage basin of North America. In Chambers, F. M. (ed.), Climate Change and Human Impact on the Landscape. Chapman and Hall, New York: 237-245.

Warner, B. G., 1996. Vertical gradients in peatlands. In Mulamoottil, G., B. G. Warner \& A. E. McBean (eds.), Wetlands. Environmental Gradients, Boundaries, and Buffers. Lewis Publisher, Waterloo: 45-66.

Warner, B. G., H. J. Kubiw \& K. I. Hanf, 1989. An anthropogenic cause for quaking mire formation in southwestern Ontario. Nature 340: 380-384.

Weckström, J., A. Korhola, P. Erästö \& L. Holmström, 2006. Temperature patterns over the past eight centuries in Northern Fennoscandia inferred from sedimentary diatoms. Quaternary Research 66: 78-86.

Wiederholm, T., 1983. Chironomidae of the Holarctic Region. Keys and Diagnoses. Larvae, Vol. 1. Entomological Society of Lund, Sweden: $457 \mathrm{pp}$.

Williams, M., 2000. Dark ages and dark areas: global deforestation in the deep past. Journal of Historical Geography 26: $28-46$.
Willis, K. J., M. B. Araujo, K. D. Bennett, B. Figueroa-Rangel, C. A. Froyd \& N. Myers, 2007. How can a knowledge of the past help to conserve the future? Biodiversity conservation and the relevance of long-term ecological studies. Phil Trans R Soc 362: 175-186.

Wilson, R. S. \& L. P. Ruse, 2005. A guide to the identification of genera of chironomid pupal exuviae occurring in Britain and Ireland (including common genera from Northern Europe) and their use in monitoring lotic and lentic fresh waters. Freshwater Biological Association Special Publications 13, 176 pp.

Woś, A., 1999. Klimat Polski. Climate of Poland. Wydawnictwo Naukowe PWN, Warszawa: 302 pp. (in Polish).

Yeloff, D. \& D. Mauquoy, 2006. The influence of vegetation composition on peat humification: implications for palaeoclimatic studies. Boreas 35: 662-673.

Yeloff, D., P. Broekens, J. Innes \& B. v. Geel, 2007. Late Holocene vegetation and land-use history in Denmark: a multi-decadally resolved record from Lille Vildmose, northeast Jutland. Review of Palaeobotany and Palynology 146: 182-192.

$\mathrm{Yu}, \mathrm{Z}$., 2006. Holocene carbon accumulation of fen peatlands in boreal western Canada: a complex ecosystem response to climate variation and disturbance. Ecosystems 9: 1278-1288.

Zajączkowski, S. \& S. M. Zajączkowski, 1966. Materiały do słownika geograficzno-historycznego dawnych ziem łęczyckiej i sieradzkiej do 1400 roku, Część I. (Materials for geographical-historical dictionary of old Łęczyce and Sieradz lands until AD 1400. Part I (Abramowice Mzurki)) Łódź (in Polish).

Zobel, M., 1988. Autogenic succession in boreal mires-a review. Folia Geobotanica \& Phytotaxonomica 23: 417-445. 